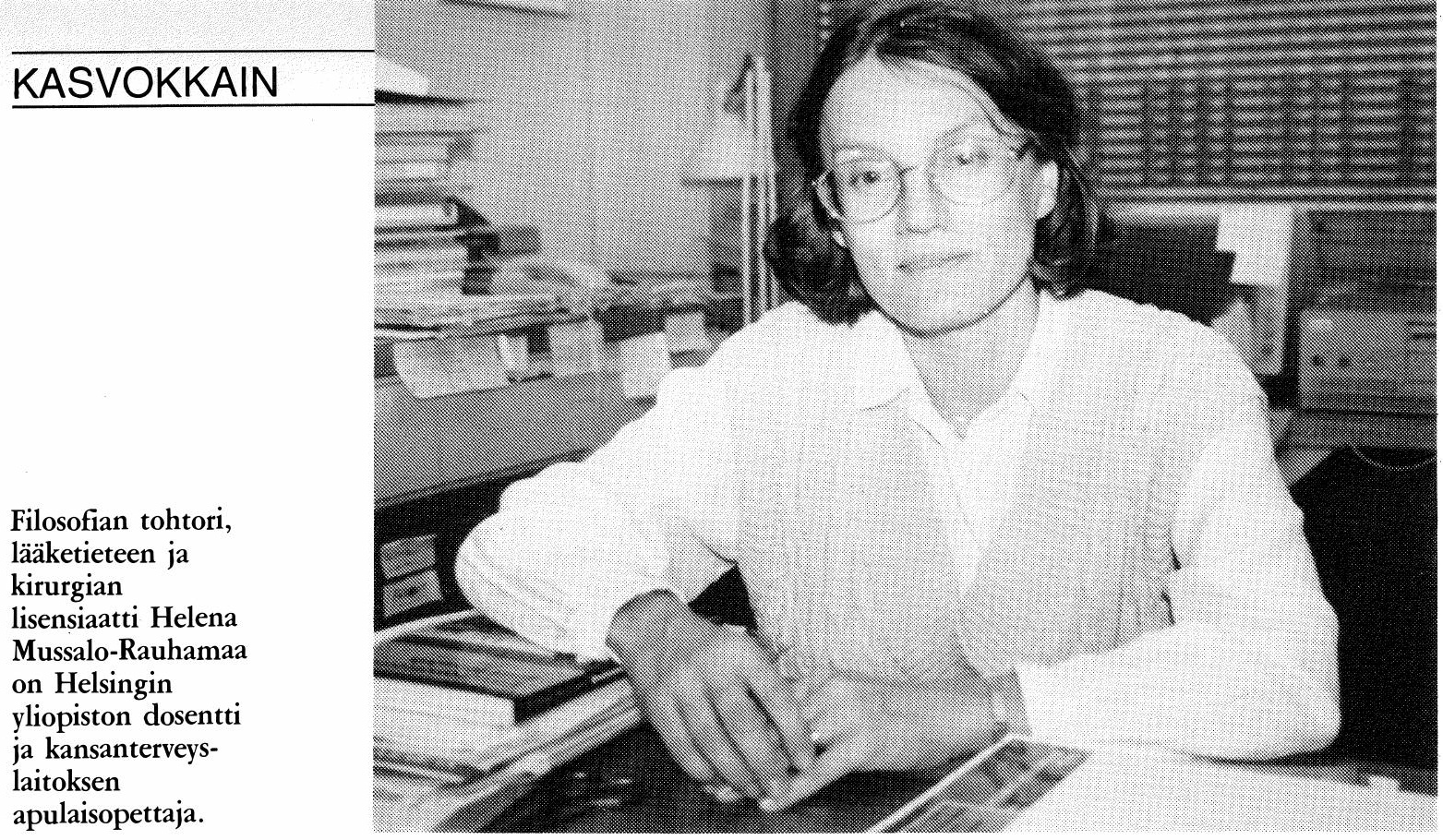

Helena Mussalo-Rauhamaa:

\title{
YMPÄRISTÖNHOITO ON MYÖS TERVEYDENHOITOA
}

Jos lääketieteessä tämän vuosisadan mullistavia löytöjä oli penisilliini, oli se ympäristötietämyksessä oivallus siitä, että ympäristö voi aiheuttaa terveysseuraamuksia ja että seuraamukset voivat tulla jo vähäisistäkin altistumisista. Ympäristölääketiede onkin tieteen nuoria aluevaltauksia, vasta kehittymässä.

Alan ensimmäinen suomenkielinen oppikirja on viimeisteltävänä. Sen toimittavat Helena Mussalo-Raubamaa ja Jouni Jaakkola ja teos ilmestyy ensi syksynä Duodesimin kustantamana. Alan nuoruutta kuvaa se, että kirja on samalla aivan ensimmäisiä maailmassa.

Eri oppilaitoksille, mm. lääkärikoulutukseen, terveydenhoitajille ja aikuiskasvattajille tarkoitettu kirja välittää ympäristölääketieteen nykytietämystä ja ohjaa ehkäisevään terveyskasvatukseen.
Kun perinteinen lääkärintyö ja lääkärikoulutus ohjaavat diagnoosin tekoon ja sairaudenhoitoon, toisenlainen, ennalta ehkäisevä työskentely on välttämätöntä tulla mukaan myös lääkärin työhön. Kun taloudellisten mahdollisuuksien niuketessa on pakko säästää, tulee halvemmaksi hoitaa ennalta ehkäisten.

Ympäristön ja terveyden yhteydestä on kyllä tiedetty vanhastaan kokemusperäisesti. Euroopan ensimmäinen ilmansuojelulaki syntyi 1200-luvun Englannissa ja 1500-luvulla Elisabet I kielsi polttamasta hiiltä parlamentin kokoontumisen aikana. Vaikka trikiiniä ei tunnettu, sianlihan syöntikielto arabikulttuureissa pohjasi enemmän kokemuksiin kuin alun alkaen uskontoon.

"'Hygienia oli Antiikin kreikkalaisten terveyden ja puhtauden jumalatar." 
Oman vuosisatamme terveyden suuria uhkatekijöitä ovat kemikalit, niissä synteettisten aineiden luvuton määrä ja ennen muuta eri tekijöiden mahdollinen yhteisvaikutus.

\section{Tutkimuksia ja valistustyötä}

Helena Mussalo-Rauhamaa on lääkäri ja luonnontieteilijä, joka tekee ympäristölääketieteen perustutkimusta ja tekee kirjoittamalla ja esitelmöimällä terveyskasvatustyötä omalla alueellaan. Kohteina ovat ennen muuta lääkärit, mutta myös muu terveydenhoitohenkilökunta. Aikuiskasvatustyötään Mussalo-Rauhamaa sanoo "mielekkääksi'. Koulutustilaisuuksissa kiertämisen kannustimena ei ole raha - se kun näissä töissä liikkuu säästeliäästi. Asian merkityksestä täytyy olla itse innostunut.

Innostus on myös tutkimustyön kannustimena. Helena Mussalo-Rauhamaa sanookin, että tosiasiassa tutkijat rahoittavat itse valtaisat määrät yhteiskunnan kannalta tärkeää tutkimustyötä mm. hankkimalla omin kustannuksin välineitä ja kirjallisuutta. Helena Mussalo-Rauhamaan peruskoulutus on luonnontieteissä. Suuntautuminen radiokemistiksi ja ydinsäteilyn vaikutusten tutkijaksi johdatti hänet uudelleenkoulutukseen. Hän päätti lukea myös lääkäriksi. Nykyisellään Helsingin yliopiston kansanterveyslaitoksen tutkijana hän yhdistää nämä kaksi osaamisensa alaa ympäristölääketieteessä.

Parast'aikaa, rinnan oppikirjan viimeistelyn kanssa Helena Mussalo-Rauhamaa tekee vertailevaan kansainväliseen aineistoon perustuvaa tutkimusta nuorten suhtautumisesta ympäristön saastumiseen. Virolaisen, venäläisen, belgialaisen ja suomalaisen aineiston pohjalta halutaan selvittää saastumisen vaikutusta nuorten asenteisiin ja pelkoihin.

Tutkimuksessa selvitetään mm. nuorten käyttäytymistä, esimerkiksi paljonko hän tupakoi ja milloin hän on alkanut käyttää alkoholia. Tutkitaan siis mm. sitä, mitä nuoret tietävät ympäristöperäisistä terveyshaitoista ja miten se vaikuttaa heidän elintapoihinsa. Kohdemaat ovat mielenkiintoiset erilaisuutensa ja ympäristön erilaisen kuormittumisen vuoksi.

\section{Suomalainen tupakoi itsensä hengiltä}

Yksi tyypillisesti suomalainen piirre on helposti nähtävissä aiemmin jo julkaistuista suomalaisista tutkimuksista: suomalaisten, ennen muuta nuorten naisten, runsas tupakointi.

"'20- ja 30-luvulla eniten tupakoivia ihmisiä maailmassa olivat suomalaiset miehet. Se on näkynyt keuhkosyövän esiintyvyydessä. Nyt miesten osalta keuhkosyöpäkäyrä on laskussa, mutta naisilla tupakointi tulee näkymään noin vuodesta 2005 lähtien syöpäänsairastumisen lisääntymisenä."

"'Yhdysvalloissa tupakka ei kuulu enää menestyvän ihmisen imagoon. Tämä amerikkalainen imagonmuutos ei ole toistaiseksi näkynyt suomalaisissa nuorissa naisissa. En tiedä, miksi tupakkatieto ja runsas tupakkavalistus eivät ole purreet. Ehkä yksi selittäjä on yhteisön arvot. Yleinen asenne kouluissa on tupakkamyönteinen."

Terveyskasvatus ja alan innovaatiot ovat yhdessä tuottaneet joillakin muilla alueilla kauniita tuloksia. Esimerkiksi ennaltaehkäisevän hammashoidon ansiosta hammaslääketieteen laitoksia saadaan nyt lopettaa.

\section{Ympäristölääketieteellä on erityistutkittavaa}

Vaikka Suomi kansainvälisissä tilastoissa onkin verrattain puhdas maa, ympäristölääketieteellä on kiistaton oma työkenttänsä myös meillä. Esimerkiksi Helena Mussalo-Rauhamaa nostaa oululaisten, vaasalaisten ja rovaniemeläisten lasten vertailevan tutkimuksen infektioalttiudesta. Tässä vuonna 1986 tehdyssä tutkimuksessahan kävi ilmi, että oululaiset lapset sairastuivat vertailukaupunkien lapsia huomattavasti herkemmin. Kuitenkaan Oulu ei ole kansainvälisesti "'likainen"' kaupunki. "'Terveyshaitat ovat hyvin olosuhteisiin sidottuja asioita. Meillä voi siis löytyä meille ominaisia tekijöitä, kuten kylmä ilmasto, jotka vaikuttavat erilailla kuin esimerkiksi olosuhteet Keski-Euroopassa. Siksi johtopäätöksiä ei voida tehdä sillä perusteella, miltä saastemäärätilastot näyttävät ja mitkä ovat asetetut päästönormit."' 
Toinen terveyteemme vaikuttava, vaikeasti tutkittava seikka on eri tekijöiden yhteisvaikutus. Tiedetään esimerkiksi, että melu vaikuttaa kuuloon. Voi myös olla saasteita, jotka vaikuttavat kuuloon. Entä jos tällainen kemikaali ja melu vaikuttavat yhdessä? Onko niiden yhteisvaikutus suurempi kuin molempien erikseen yhteenlaskettuna?

\section{Ilmansaasteet ja tupakka ratkaisevat rasittajat}

Kun tarkastelemme ihmisen altistumista ympäristöönsä, ilmansaasteet on selkeä ykkönen. Useimmat reagoivat varsin pieniinkin ärsykkeisiin. Ympäristön puhdistamisen tulisi Helena Mussalo-Rauhamaan mielestä lähteä juuri ilmansaasteista.

Helena Mussalo-Rauhamaa käyttää selkeästi termiä "saaste" miedontamatta tai neutraloimatta sitä.

Tupakansavu lyö kaikki muut ilman epäpuhtaudet. Sen vaikutus yksin on niin voimakas, että sen rinnalla muuten likainen ilma on pieni vaikuttaja.

Nyt suomalaistutkijat ovat tekemässä tupakoinnin ja keuhkosyövän välisiin yhteyksiin liittyvää tutkimusta, joka saattaa mullistaa terveyskasvatusta tältä osin. Professori Olli P. Heinonen selvittää yhdessä kansanterveyslaitoksen tutkijoiden kanssa E-vitamiinin ja beetakaroteenin (A-vitamiinin esiasteen) yhteyttä syövältä suojautumiseen. Tutkimuksessa on mukana 30000 suomalaista miestä.

'Jos yhteys kiistattomasti löytyy, saattaa tulevaisuuden terveyskasvatusta tupakoitsijoille olla vitamiinipillerin popsiminen päivittäin. Kuka tietää, vaikka tulevaisuudessa tupakanvalmistajat alkavat lisätä tuotteisiinsa A-vitamiinia samalla tavalla, kuin jauhoihin lisätään rautaa tai juomaveteen fluoria."

\section{Tutkimuksella yhteys päätöksentekoon}

Helena Mussalo-Rauhamaa toivoo ympäristölääketieteen tulosten näkyvän myös yhteiskunnal- lisessa päätöksenteossa. Jos lääkäreillä olisi ympäristön terveysvaikutuksista riittävästi tietoa, voisivat he olla tärkeitä lausunnonantajia kunnissa esimerkiksi päätettäessä kaavoituksista, tehtaan sijoituksista ja normeista.

Energiapoliittinen päätöksenteko on tässä mielessä tärkeimpiä. Kun esimerkiksi hallituksen energiapoliittisessa linjauksessa näkyy yhtenä vaihtoehtona kotimainen puu, pitää MussaloRauhamaa sen mahdollista laajamittaista käyttöä terveyden kannalta heikkona vaihtoehtona:

,'Puun polttaminen, savusaunat ja tupakan savu sisältävät runsain määrin syöpää aiheuttavia PAH-aineita. Jos entisajan ihmiset olivat eläneet yli 40-vuotiaiksi, olisivat he todennäköisesti kuolleet keuhkosyöpään. Infektiot veivät kuitenkin sitä ennen. Kun Turun keskustassa alettiin rakentaa hotellia, jonka alta löytyi keskiaikainen hautausmaa, hautoja tutkittaessa kävi ilmi, ettei juuri kukaan ollut elänyt yli 50-vuotiaiksi. Pääasiassa kuoltiin kuitenkin lapsena."

\section{Valikoivaa terveyskasvatusta}

Entä keille terveyskasvatusta yleensä tulisi suunnata? Helena Mussalo-Rauhamaa kannattaa valikoivaa terveyskasvatuksen kohdentamista. Esimerkiksi kolesteroli ei ole naisten ongelma. Oikea kohderyhmä olisi näin ollen jotkut miesryhmät. "'Mutta informaatio voidaan toki suunnata naisillekin. Tällöin he toimivat välittäjinä, välikäsinä', Mussalo-Rauhamaa pohtii.

Teksti ja kuva: ANNELI KAJANTO 